$\underset{n=m}{=\infty}$ मूล $\longrightarrow$

\title{
HOTEL PERFORMANCE MEASUREMENT: LITERATURE REVIEW
}

\section{Mladen Mitrović ${ }^{1}$ \\ Sandra Janković ${ }^{2}$ Gordana Ivankovič ${ }^{1}$}

${ }^{1}$ Faculty of Tourism Studies - Turistica, Portorož, Slovenia

${ }^{2}$ Faculty of Tourism and Hospitality Management, Opatija,Croatia
Correspondence:

Mladen Mitrović

e-mail:

mladen.mitrovic@live.com

\begin{abstract}
:
Competitive business environment with changing circumstances and numerous stakeholders' pressures is forcing hotels to make stronger efforts towards satisfying different customer groups. Performance measurement has become a very important tool in preparing a business strategy and it helps the hotels to determine their position on the demanding tourism market. The purpose of this paper is to determine the development of hotel performance measurement practices based on the previous research and literature review. It also provides an overview of the current research in the field of hotel accounting and segment reporting. The study provides insights into the problem of performance measurement and its implementation by hotel management.
\end{abstract}

Keywords:

performance measurement, accounting, balanced scorecard, USALI, activity based costing.

\section{INTRODUCTION}

Due to an increasingly competitive environment, performance measurement is of vital importance. The model of performance measurement enables the management to make decisions appropriate for the hotel industry and enhanced performances of the organisation. Information needed for decision making lies in the domain of the management accounting system (MAS), which has to be appropriately developed and organized. Undoubtedly, the MAS differ substantially in the hotel industry compared to other industries. Hotel enterprises have unique characteristics of their operations, as they bring together many activities that are essential for guest satisfaction (Ivankovič \& Jerman, 2011). It is well known that value is of great importance for guests and employees in the hotel industry. The choice of performance measurement is nowadays the most significant challenge in the hotel industry. Nevertheless, exaggerated performance measurement is problematic as hotels want to quantify almost everything. The present challenge is not to find out what can be measured, but what should be measured. Performance measurement helps in the implementation of the goal-oriented strategy. It is an element of value-based management used to determine the value of the hotel for the owners and to meet the interests of other stakeholders. Moreover, performance measurement is a critical component of human resources management, as well as an integral part of management award and promotion. 
Strategic management accounting is focused on value added for guests, market share and long-term strategic budgets or long-term accepted strategy. Since the effectiveness of a company depends on its capability to achieve the goals, its performance cannot be left to chance, but has to be planned. For a successful future performance, directed business operations should be performed. To that end, management has to be in possession of high-quality information, which is in the domain of budgeting. Continuous budgets provide information about deviations between planned and realized categories. (Ivankovič \& Jerman, 2011)

Uyar and Bilgin (2011) state that organizations use budgets for various reasons. Some of the most prominent benefits of budgeting are forecasting the future, assisting in profit maximization, performance evaluation, pricing decisions etc. All together with USALI, Balanced Scorecard, Activity Based Costing and Revenue Management in function of benchmarking, budgeting represents a comprehensive process of Performance Measurement.

\section{HOTEL PERFORMANCE MEASUREMENT}

The business environment in the hotel industry is characterized by fierce competition and constantly changing circumstances. Each hotel is in direct or indirect competition with every other hotel. Strong competition forces management to try to get closer to their guests wishes, since it is the only way to achieve success (Ivankovič et al., 2009). Therefore, it's no wonder that hotel management is more and more committed to establishing Performance Measurement (PM) System in order to show, in the best possible way, which weaknesses are observed in the business and where the improvement could be made to be able to satisfy the needs of all stakeholders.

$\mathrm{PM}$ as a tool of management accounting in the decision-making process became popular in the 1990s by both practitioners and academics (Haktanir, 2006; Atkinson, 2006; Kaplan, 1994; Neely et al., 2000). Pnevmatikoudi and Stavrinoudis (2016) notice that many authors consider that the concept of performance is of great significance for the business strategy of a company, its competitive position, and long-term economic sustainability. They also state that "performance and its measurement are the key success factors for every tourism enterprise." As stated by Bourne et al. (2003), there was a lack of definitions about PM. In his paper, Haktanir (2006) proposed the following definition from Neely et al (1995):"PM is the process of quantifying actions, where measurement is the process of quantification and action leads to performance."

With the growth in international travel and therefore, increasing demand on hospitality businesses, performance measurement in the hospitality industry has gained particular importance as a tool for effective decision-making (Haktanir, 2006).

PM has been used in the hospitality industry for a long time as an important component of the decision making process. It offers hotel management the possibility to make decisions that could ensure the best possible results, taking into account the special characteristics of the hotel business (Ivankovič et al, 2010). Although there are several reasons for using the performance measures (to indicate the level of effort, to monitor activities in units, continuous improvement, motivating employees etc.), overall, it is considered to be an integral part of the management processes, which means it identifies the areas of poor performance or opportunities so that better plans can be developed (Haktanir, 2006). Traditional performance measurement has been strongly oriented to financial performance. This approach has numerous weaknesses such as short-termism, lack of balance and strategic focus, customers approach, performing of competition etc. (Atkinson and Brander Brown 2001; Haktanir 2006; Atkinson, 2006; Ivankovič et al. 2010), and was strongly criticized for providing a limited perspective on the performance of the company. As hotel industry is a people-oriented industry, non financial indicators of PM are also important. They are valuable supplements to financial measures as they are expected to supply information that would improve the financial outcome and support and monitor the strategic initiatives (Haktanir, 2006). Atkinson and Brander Brown (2001) emphasize the increasing recognition within the hotel industry of the importance and value of people, employees as well as guests. Therefore, the economic and financial success of a hotel depends on the attitude and behavior of employees, development of new products and services, as well as customer satisfaction. Hotel General and Department Managers must recognize equal importance to the goals of all stakeholders and not only of their shareholders. The achievement of objectives of all stakeholders (guests, employees, strategic partners, community etc.) can be measured by both financial and non-financial measures (Ivankovič et al., 2010).

There are a lot of authors who have been examining the importance, implementation and improvement of the PM process. The overview of their papers is given in Table 1. 
Table 1. Overview of previous research in the field of hotel Performance Measurement

\begin{tabular}{lll}
\hline \multicolumn{1}{c}{ Author } & $\begin{array}{c}\text { Original title and year } \\
\text { of publication }\end{array}$ & \multicolumn{1}{c}{ Purpose and contribution of the paper } \\
\hline $\begin{array}{l}\text { Pnevmatikoudi, K., } \\
\text { Stavrinoudis, T. }\end{array}$ & $\begin{array}{l}\text { plassification of hotel } \\
\text { performance measure- } \\
\text { sented in international } \\
\text { scientific research }(2016)\end{array}$ & $\begin{array}{l}\text { The paper provides an overview of PM indicators used by researchers } \\
\text { and their classification. The main purpose of the article is to provide } \\
\text { both researchers and hotel management with better understanding of } \\
\text { the indicators, and also to have an effect on their efficient use. }\end{array}$ \\
\hline Sainaghi, R. & $\begin{array}{l}\text { Hotel performance: state } \\
\text { of the art (2010) }\end{array}$ & $\begin{array}{l}\text { This paper analyzes literature in order to provide answers on how the } \\
\text { success of a hotel business is measured and what factors determine } \\
\text { performances. The analysis shows the growing importance of the BSC } \\
\text { as a satisfactory PM system. }\end{array}$ \\
\hline $\begin{array}{l}\text { Zigan, K., } \\
\text { Zeglat, D. }\end{array}$ & $\begin{array}{l}\text { Intangible resources in } \\
\text { performance measure- } \\
\text { ment systems of the } \\
\text { hotel } \\
\text { Industry (2010) }\end{array}$ & $\begin{array}{l}\text { The purpose of this research was to increase the understanding and } \\
\text { importance of intangible resources for the hotel industry and to empha- } \\
\text { size the need for development and applying PM systems that include } \\
\text { this type of resources as well as the need for hotel managers to apply } \\
\text { them in their organizations. }\end{array}$ \\
\hline
\end{tabular}

Ivankovič, G., Janković, S., Peršić, M.

Framework for performance measurement in hospitality industry - case study Slovenia (2010)
The research was carried out on the sample of Slovenian hotels with over 100 rooms. The results show that most hotels have poor economic performance, which is the result of inadequately developed PM system.

In this paper, the author investigates PM practice of independent hotels in Northern Cyprus. He divides these hotels into two groups, remotely owned and owned managed. The findings indicate that PM in independent hotels is influenced by various factors. For example, the degree of owner's involvement in business process restrict the flow of information and limit the involvement of managers and employees, which affects the way management operates and PM takes place.

Performance measure-

Haktanir, M. ment in independent hotels (2006)
Performance measurement in the internation-

Atkinson, $\mathrm{H}$ al hospitality industry (2006)

Implementing perfor-

Bourne, M., Neely, A. mance measurement systems: a literature review (2003)
This article provides an insight into PM in hospitality industry according to previous literature, reviews the weaknesses of traditional PM and proposes areas for future research. It emphasizes the importance of combining financial measures with non-financial measures.

The authors analyze different performance measurement system design processes published in the literature and create the framework for comparing the alternative approaches. There are many companies interested in implementation of BSC, but the attempts are usually not successful. The purpose of the paper is to contribute to better understanding of the factors which influence the success or failure of performance measurement initiatives by reviewing the literature.

There is a growing interest from hotel managers to change the way of measuring the business performance. Anyway, there is a difference between managers' opinions on what determines their success and what they in fact measure, and the difference in understanding between managers in different functions of the importance of particular indicators to overall success. The research was conducted on a sample of Croatian hotels and different function managers. Conceptual framework for measuring performance is provided.

The authors explore the attitudes of UK hotels using PM. They are very traditional, focused on short term, and that can lead to overlooking some important issues. The impression is that hotels measure wrong things. Potential developments are given, and the development of a balanced range of performance measures is one of the most important. Identification of Critical Success Factors (CSF) could also be crucial for hotels PM. 
As stated, successful PM required a comprehensive approach with both financial and non financial measures to be included. The most popular measurement tool which covers different aspects of business is Balanced Scorecard developed by Kaplan and Norton (1992). It provides a multifaceted view of an organization business performance (Atkinson \& Brander Brown, 2001; Atkinson, 2006). BSC includes four different perspectives: Customer perspective, financial perspective, Internal Business perspective and Learning and Growth Perspective. The important feature of the scorecard is the clear link between the corporate strategy and measures throughout the organization. By focusing on the four perspectives, managers can articulate their core vision, strategy and goals before translating them into specific measures, targets and initiatives (Atkinson, 2006).

BSC gives hotel management information from different perspectives, which is important for company's business, but it has one more core function. It also minimizes the potential of information overload by limiting the number of individual measures included (Brander Brown \& McDonnell, 1995). According to this, Atkinson and Brander Brown (2001) state that the selection of number of performance measures is a comprehensive strategic appraisal process which should lead to the clear identification of an organization's strategic objectives and their related key success factors, and consequently should enable management to develop the appropriate and effective balance of measures.

Nowadays, companies are faced with changes in the business environment. Relevant sustainability and social responsibility information should be prepared and disclosed in a statement according to the new EU financial Directive 2014/95/EU, which has to contain nonfinancial and bio-diversity information, and are responsible for large undertakings and groups. To provide relevant information in accordance with the EU Directive as well as the need of strategic management Sustainability Balanced Scorecard method (SBSC) is used. SBSC is an upgraded principle of BSC method and focuses on ecology, as the fifth perspective.

\section{SEGMENT REPORTING IN HOTELS}

The basic idea behind responsibility accounting information systems is that each manager's performance should be judged by how well they manage the items under their control. Segment reporting in responsibility accounting personalizes the accounting information, by looking at costs and revenues from a personal control standpoint. For management in hotel enterprises, each manager is assigned responsibility for the items of revenues and costs under their control, and for deviations between budgeted goals and actual results (Peršić et al., 2012).

The information needed for decision making falls within the domain of the segment reporting system, which has to be appropriately developed and organized. Undoubtedly, the use of the segment reporting system in the hospitality industry differs substantially from its use in the manufacturing industry. Operations of hotel enterprises have some unique characteristics due to the various activities involved, essential for guest satisfaction, which is reflected in a full range of manufacturing, service and retail operations found within it.

The basic accounting system in hospitality industry is Uniform System of Accounts for the Lodging Industry (USALI). USALI has had a long tradition since its first version was established in 1926 by the Hotel Association of New York City. The purpose was the attempt of creation and definition of one unique standard for internal reporting in Hospitality Industry, according to the growing interest in benchmarking between hotels. It represented the first successful organized effort to establish a uniform responsibility accounting system for the hotel industry and one of the first such efforts in any industry (Janković et al., CPA 2012).

Guilding (2014) quotes the following significant benefits of using this system:

- it represents an "off the shelf" accounting system that can be adopted by any business in the hotel industry,

- the system can be viewed as "state of the art" as it benefits from the accumulated experience of the parties that have contributed to the system's development over many years,

- by promoting consistent account classification schemes as well as consistent presentation of performance reports, it facilitates comparison across hotels,

- it represents a common point of reference for hotels within the same hotel group.

USALI represents an essential framework for the introduction of responsibility accounting information systems in hotels, in other words, for defining the monitoring and reporting of all types of revenue and costs by individual departments (Janković \& Poldrugovac, 2015).

It enables the evaluation of the performance of departmental managers based on revenues and costs within their control. The departmental statements of income provide some of the most important internal sources of information for hotel managers (Janković et al., 2012). 
Since the publication of its first edition in 1926, USALI has had 11 revised editions with the latest one published in 2014. With an almost 90-years long tradition, it is not surprising that USALI was constantly improved and changed, in order to be more understandable to users. The $11^{\text {th }}$ revised edition, which contains five sections, was analyzed by Schmidgall and DeFranco (2015), and they pointed out to several changes compared to the $10^{\text {th }}$ edition. Some of them are:

- In the first section, operating statements, aimed at providing information for internal users, there are several differences. The $11^{\text {th }}$ edition provides two Operating Statements, one for the operators and one for the owners. The next is additional schedule "Information and Telecommunications Systems" which is shown in the undistributed operating expense (UOE) section of the summary operating statement. The schedule "Rentals and Other Income" is renamed as "Miscellaneous Income".

- The second section is Financial Statements, which is aimed at external users (bankers, potential investors). The main innovation in this section is the Statement of Comprehensive Income which reflects changes in U.S. GAAP.

- The third section Ratios and Statistics changed its name to Financial Ratios and Operating Metrics. The recommended labor cost schedule is included for each department, since they are the biggest expense line item in the hotel business.

- The fourth section also changed its name from Expense Dictionary to Revenue and Expense Guide. It provides more sophisticated classification by individual items, departments/schedules and accounting names.

- The last fifth section is completely new $\left(10^{\text {th }}\right.$ edition has only four), and is called Gross Versus Net reporting. It shows the treatment of surcharges, service changes, and gratuities.

Generally, the authors conclude that the new $11^{\text {th }}$ edition is more user-friendly and provides new guidance in a number of important areas. In support of this assertion is the fact that the entire book of the $11^{\text {th }}$ revised edition is available in electronic form, which is a considerable advantage compared to previous editions.

Although USALI provides a lot of important information, it is still considered insufficient. For the revenue decision makers, it is important to know the overall cost of profit or cost centre. As USALI does not allocate the hotel overhead costs, it should be used only with supplementation of Activity Based Costing (ABC) method.
According to Janković et al. (2012), ABC is a methodology that measures cost and performance of activities, resources and cost objects, where resources are assigned to activities, then activities are assigned to cost objects based on their use. ABC method is also useful in calculation of customer profitability. Customers differ in their consumption of resources and level of profitability. When using $\mathrm{ABC}$, firms first identify cost pools: categories of activities performed within the organization (e.g. procurement). For all cost pools, cost drivers are identified - units in which the resource consumption of the cost pools can be expressed (number of purchase orders). Costs are then allocated to cost objects (e.g. products) based on the extent to which these objects require certain activities (measured in cost driver units) (van Raaij et al., 2003). It is concluded that ABC provides better insights into customer profitability than the traditional costing systems.

Pavlatos and Paggios (2009) list numerous benefits of $A B C$ adoption in their paper. Those are: more accurate cost information for product costing, improved cost control, cost reduction, more accurate allocation of indirect costs, improved insight into cost causation, identification of activity costs, improvement of operational efficiency, more accurate cost information for pricing, help in preparing of relevant budgets. The authors also state the suggestion of Kaplan and Cooper that service companies are ideal candidates for $\mathrm{ABC}$ implementation even more than manufacturing companies because most of the costs in service organizations are fixed and direct.

In general, $\mathrm{ABC}$ method helps hotel managers to determine which services to provide, which customers are profitable, whether its product mix needs changing, and where it should direct its market focus and points out to opportunities for cost reduction (Janković et al., 2012).

There are numerous scientific papers that cover the topic of segment reporting in hotel industry. They are shown in Table 2.

\section{CONCLUSION}

There is abundant theoretical and empirical literature dealing with the topic of the Performance Measurement in hotels. Those papers provide both theoretical background and practical research. The review of relevant literature provides the findings that measuring of the hotel performance is a very comprehensive process.

Some of the core components of Performance Measurement are presented (with their latest versions) in Fig. 1. An important thing is that, if hotel managers want 
Table 2. Overview of previous research in the field of hotel Segment reporting

\begin{tabular}{|c|c|}
\hline Author & $\begin{array}{l}\text { Original title and year } \\
\text { of publication }\end{array}$ \\
\hline $\begin{array}{l}\text { Pnevmatikoudi, K., } \\
\text { Stavrinoudis, T. }\end{array}$ & $\begin{array}{l}\text { Classification of hotel } \\
\text { performance Measure- } \\
\text { ment indicators pre- } \\
\text { sented in international } \\
\text { scientific research }(2016)\end{array}$ \\
\hline $\begin{array}{l}\text { Schmidgall, S., R., } \\
\text { DeFranco, A. }\end{array}$ & $\begin{array}{l}\text { Uniform System of Ac- } \\
\text { counts for the Lodging } \\
\text { Industry, } 11^{\text {th }} \text { Revised } \\
\text { edition: The New Guide- } \\
\text { lines for the Lodging } \\
\text { Industry (2015) }\end{array}$ \\
\hline Schmidgall, S., R. & $\begin{array}{l}\text { Evolution of the Uniform } \\
\text { System of Accounts for } \\
\text { the lodging industry } \\
(2014)\end{array}$ \\
\hline $\begin{array}{l}\text { Basuki, B., } \\
\text { DwiputriRiedian- } \\
\text { syaf, M. }\end{array}$ & $\begin{array}{l}\text { The Application of Time } \\
\text { Driven Activity-Based } \\
\text { Costing in the Hospitality } \\
\text { Industry: An exploratory } \\
\text { Case Study (2014) }\end{array}$ \\
\hline
\end{tabular}

Purpose and contribution of the paper System of Accounts for the lodging industry (2014)

The paper provides an overview of PM indicators used by researchers and their classification. The main purpose of the article is to provide both researchers and hotel management with better understanding of the indicators, and also to have an effect on their efficient use.

As stated in the title, the authors analyzed the $11^{\text {th }}$ edition of USALI published in 2014. In the first part of the article, they remind of importance and evolution of USALI. The second part provides innovations and differences between the $11^{\text {th }}$ and $10^{\text {th }}$ edition.

In this paper, the author analyzed the evolution of the USALI from the first to $10^{\text {th }}$ edition (in that moment $11^{\text {th }}$ edition was in preparation). Over the years, USALI had undergone many changes in order to be more understandable to management. Besides the content, USALI was changed in terms of terminology (profit and loss statement became income statement in $5^{\text {th }}$ edition, Departmental Statements of Income became Operating Statements in $10^{\text {th }}$ edition etc.)

The authors conduct research on Hotel GrahaCakra, in order to compare TDABC method with the initial cost calculation method used by the hotel. TDABC represents a new approach of measuring costs developed after the problems of $\mathrm{ABC}$ implementation appeared, simpler and more suitable for a service company such as a hotel. In the research, they used Room Division as the main source of the hotel's revenue as a cost object.

There is a notable difference between the customers and their profitability. To keep the most profitable customers satisfied, managers must take into account the relevant revenue and costs, to determine the customer segments that generate the greatest profit contribution. Calculating the customer profitability is possible only with the usage of ABC method. The empirical research was carried out in Croatian hotels and the aim was to examine the use of strategic - oriented accounting in the Croatian hotel industry.

In this paper, the authors examine the usage of segment reporting standards in Croatian hospitality industry with comparation to four previous surveys. The results show an increasing implementation of USALI methodology and a growing trend of segment reporting usage and preparation by middle and low management, which should result in better authority and responsibility of managers to improve the overall profitability of the hospitality industry.

Peršić, M., Janković, S., Poldurgovac, K. mpent retion of ment reporting standards in the hospitality industry - a comparative study (2012)

Implementation of time-driven activity-

Hajiha, Z., Safari Alishah, S. based costing system and customer profitability analysis in the hospitality industry: evidence from Iran (2011)

Accounting research in the Cornell Quarterly: A review with suggestions for future research (2010)

Hesford, J. W. Potter, G

Activity-Based Costing in

Pavlatos, O., the Hospitality Industry: Paggios, I. Evidence From Greece (2009)
The purpose of this research was to examine the importance of the adoption of TDABC costing system in hospitality industry and to analyze different customer groups. Iranian Hotel Parsian was used for the case study. The results showed that TDABC provides more accurate data on cost and customer profitability than the traditional system.

This article provides a very comprehensive review and analysis of accounting related articles published in Cornell Hospitality Quarterly journal. Most of the articles are descriptive, and there is a lack of accounting research in recent years. The conclusion is that authors have contributed to understanding most accounting topics, including budgeting, costing and performance measurement.

In the article, the authors conduct research about practical considerations, adoption and use of $\mathrm{ABC}$ in hospitality industry. They also did a survey of 85 Greek hotels. 20 of them reported that they had implemented $\mathrm{ABC}$ system, which shows increasing adoption rate in Greece hotels in recent years. Most of the $\mathrm{ABC}$ non adopters (86.1\%) do not intend to adopt $\mathrm{ABC}$ in the future. 


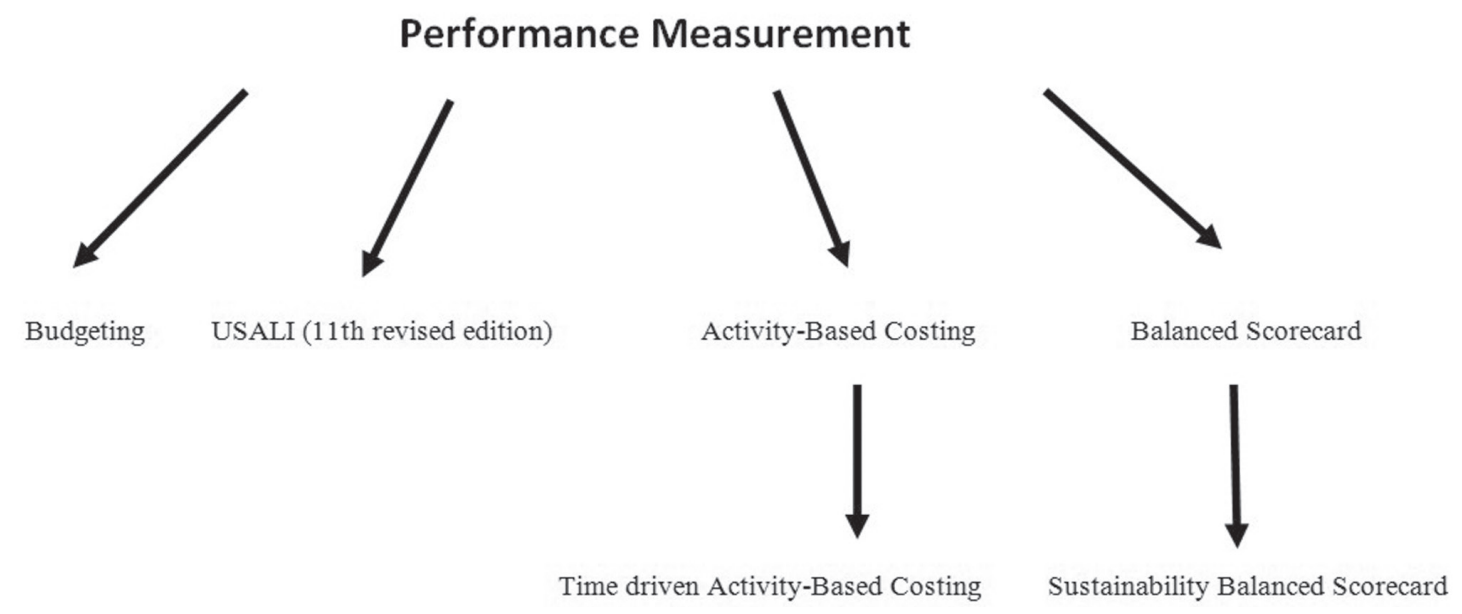

Figure 1. Components of Hotel Performance Measurement (Source: Author's research)

to have useful information from Performance Measurement to improve their business processes, all of these methods should be used integrally. Above all, budgeting process must be effective enough in order to provide the most desired effects. It has already been stated that costing in a hotel, which is based only on partial costs and USALI method, is insufficient according to new demands. Traditional costing methods are also insufficient. It is recommended to complement the USALI method with modern methods of costing, primarily, with activity based costing method because this method calculates full costs of performance and provides the basis for managing overhead costs. Although this way of measuring performance is very effective, there are still a lot of hotels which haven't implemented it, particularly the ABC method. Pavlatos and Paggios (2009) indicated in their paper some of the reasons based on many authors' research (there is considerable knowledge of the theory, but low understanding of how $\mathrm{ABC}$ might be used in hotels; satisfaction with the existing cost accounting; high cost of $\mathrm{ABC}$ implementation; lack of management interest; lack of adequate knowledge about $\mathrm{ABC}$ implementation; lack of time to access $\mathrm{ABC}$ suitability to their company; lack of appropriateness to the respondent's type of business). Performance measurement has become a very important tool for Revenue Management and the needed KPIs are provided from USALI. Revenue Management is also important as a tool for the benchmarking process, which presents hotel's success compared to its competition.

Having this in mind, it is important to raise the awareness of hotel managers about the benefits of using modern performance management system, which could provide them with a competitive advantage and long-term business success.

\section{REFERENCES}

Atkinson, H. (2006). Performance measurement in the international hospitality industry. In P.J. Harris and M. Mongiello (Eds.), Accounting and financial management: Developments in the international hospitality industry (pp. 46-70). Amsterdam: Elsevier/Butterworth-Heinemann.

Atkinson, H., \& Brander Brown, J. (2001). Rethinking performance measures: assessing progress in UK hotels. International Journal of Contemporary Hospitality Management, 13(3),128-135. doi:10.1108/09596110110388918

Avelini Holjevac, I., \& Maškarin, H. (2003). Performance management and measurement in the hotel industry: Case study of Croatia. Fifth International Conference on Enterprise in Transition (pp. 1617-1628). Split: Faculty of Economics

Basuki, B., \& Dwiputri Riediansyaf, M. (2014). The Application of Time-Driven Activity-Based Costing In the Hospitality Industry: An Exploratory Case Study. Journal of Applied Management Accounting Research, 12(1), 27-54.

Bourne, M., Neely, A., Mills, J., \& Platts, K. (2003). Implementing performance measurement systems: a literature review. International Journal of Business Performance Management, 5(1), 1-24

Brander Brown, J., \& McDonnell, B. (1995). The balanced scorecard: short-term guest or long-term resident? International Journal of Contemporary Hospitality Management, 7 (2/3), 7-11. doi:10.1108/09596119510146751

Guilding, C. (2014). Accounting Essentials for Hospitality Managers. Abingdon, Oxon: Routledge.

Hajiha, Z., \& Safari Alishah, S. (2011). Implementation of time-driven activity-based costing system and 
customer profitability analysis in the hospitality industry: Evidence from Iran. Economics and Finance Review, 1(8), 57-67.

Haktanir, M. (2006). Performance measurement in independent hotels. In P.J. Harris and M. Mongiello (Eds.), Accounting and financial management: Developments in the international hospitality industry (pp. 3-21). Amsterdam: Elsevier/ButterworthHeinemann.

Hesford, J.W., \& Potter, G. (2010). Accounting research in the Cornell Quarterly: A review with suggestions for future research. Cornell Hospitality Quarterly, 51(4), 502-512. doi:10.1177/1938965510375030

Ivankovič, G., Janković, S., \& Peršić, M. (2010). Framework for performance measurement in hospitality industry: Case study Slovenia. Economic research, 23(3), 12-23. doi:10.1080/1331677X.2010.11517420

Ivankovič, G., \& Jerman, M. (2011). Comparative analysis of budgeting in the Slovene hotel industry. Tourism and Hospitality Management, 17(1), 91-100.

Janković, S., Peršić , M., \& Zanini-Gavranić, T. (2012). Customer Profitability Approach: Measurement and Research Directions in the Hospitality Industry. 2nd Advances in Hospitality and Tourism Marketing and Management Conference: Advances in Hospitality and Tourism Marketing and Management Conference Board, Corfu 2012 (pp. 43-59).

Janković, S., \& Poldrugovac, K. (2015). Benchmarking potraga za najboljom praksom u hotelijerstvu: Praćenje i usporedba rezultata hrvatskih i slovenskih hotela. Koper: ZaložbaUniverzena Primorskem.

Neely, A., Bourne, M., \& Kennerley, M. (2000). Performance measurement system design: developing and testing a process-based approach. International Journal of Operations \& Production Management, 20(10), 1119-1145.

Pavlatos, O., \& Paggios, I. (2009). Activity-based costing in the hospitality industry: Evidence from Greece. Journal of Hospitality \& Tourism Research, 33(4), 511-527. doi:10.1177/1096348009344221

Peršić, M., Bakija, K., \& Vlašić, D. (2015). Corporate social responsibility reporting in accordance with the new EU legislation: Are Croatian hotel companies ready for it? 3rd International Scientific Conference Tourism in Southern and Eastern Europe, Vol. 3, pp. 295-308.

Peršić, M., \& Janković, S. (2006). Menadžersko računovodstvo hotela. Opatija: Hrvatska zajednica računovođa i financijskih djelatnika.

Peršić, M., Janković, S., \& Poldrugovac, K. (2012). Implementation of segment reporting standards in the hospitality industry: A comparative study. Biennial International Congress Tourism \& Hospitality Management 2012, Conference Proceedings (pp. 30-39).

Pnevmatikoudi, K., \& Stavrinoudis, T. (2016). Classification of hotel performance measurement indicators presented in international scientific research. European Journal of Tourism Research, 12, 82-98.

Sainaghi, R. (2010). Hotel performance: state of the art. International Journal of Contemporary Hospitality Management, 22(7), 920-952. doi:10.1108/09596111011066617

Schmidgall, R.S. (2014). Evolution of the Uniform System of Accounts for the Lodging Industry. The Journal of Hospitality Financial Management, 22(1),41-57. doi:10.1080/10913211.2014.912105

Schmidgall, R.S., \& DeFranco, A. (2015). Uniform System of Accounts for the Lodging Industry: The New Guidelines for the Lodging Industry. The Journal of Hospitality Financial Management, 23(1), 79-89. doi:10.1080/10913211.2015.1038196

Uyar, A., \& Bilgin, N. (2011). Budgeting practices in the Turkish hospitality industry: An exploratory survey in the Antalya region. International Journal of Hospitality Management, 30, 398-408. doi:10.1016/j. ijhm.2010.07.011

van Raaij, E.M., Vernooij, M.J.A., \& van Triest, S. (2003). The implementation of customer profitability analysis: A case study. Industrial Marketing Management, 32(7), 573-583. doi:10.1016/S0019-8501(03)00006-3

Zigan, K., \& Zeglat, D. (2010). Intangible resources in performance measurement systems of the hotel industry. Facilities, 28(13/14), 597-610. doi:10.1108/02632771011083667 